\title{
An investigation into the ease of use of a small technikon library
}

\author{
Adriaan Swanepoel, \\ Deputy Director of Library Services, Technikon Pretoria, Private Bag Pretoria 000 I, South Africa. \\ swanepA@techPTA.ac.za
}

Received: $25^{\text {th }}$ October 2002

Revised: $23^{\text {rd }}$ April 2003

\begin{abstract}
This article presents and discusses the findings of a user survey at a technikon satellite library in the Mpumalanga province. The purpose of the investigation was firstly to determine the extent to which pre-graduate students find particular library services, facilities and information sources either easy or difficult to use, and secondly to determine whether students who received library instruction found the library's services more easy to use than students who haven't received library instruction. A questionnaire to gather the information was distributed to all students entering the library over a period of seven days. Although a non-probability sampling method was used, the findings can be regarded as valid as the respondents represent $29.5 \%$ of the total student population on the campus. The results showed that of the list of library activities covered in the survey, the largest number of students regarded the use of photocopiers easy to use, while the smallest number of students regarded the online computer catalogues easy to use. The results also showed students who received library instruction did not necessarily find the library's services, facilities and information sources easy to use.
\end{abstract}

Keywords: User survey, Ease of use, Technikon libraries, Library instruction

\section{Introduction}

The purpose of this article is to present and discuss the results of a library user survey at a technikon satellite campus in the Mpumalanga province. The survey was part of a broader survey to identify services and facilities that library users find difficult to use, and to determine whether library instruction had an influence on the findings relating to ease of use. It is the intention of this article to increase awareness for further research on the issues of ease of use, and the influence of library instruction or user education on ease of use.

Although the survey was conducted at a tertiary education library, the author is of the opinion that the findings could also be of importance to other libraries serving students or young adults.

\section{Background and problem identification}

Librarians like to believe that libraries in general and their libraries in particular are easy to use. When new library buildings are designed, much effort and money are invested in trying to make them easy to access, easy to use and user friendly (Metcalf 1985: 34, 86-94; Bosman 1997:I). Librarians also perform a variety of activities to ensure that users find their services, facilities and information sources easy to use. A well-known practice is to give user education or library instruction to library users. This ranges from broad based orientation (guided tours, general information brochures) to indepth training in specialised areas like the use of a specific database or reference source. Apart from training library users to become more acquainted with their services and ultimately to use some of the facilities and information sources without the intervention of the library staff, librarians offer a vast array of personal and personalised services to make it as easy as possible for library users to get information or access thereto (Allan 2002: I-4; Abor 1996: I).

Although library staff of Technikon Pretoria are continuously involved in various activities to enhance the ease of use of their library's services and facilities, the extent to which library users actually experience it easy or difficult to use, remains unknown. Furthermore, although staff of the Library Services suspect that a fair number of first year students, especially those from rural areas, might find the library difficult to use, the validity of such opinions has not yet been tested scientifically.

\section{Research objectives}

When it became clear that library managers of Technikon Pretoria needed more precise information about how easy it is to use their libraries, they identified a number of issues to be investigated. The objectives of this investigation, therefore, were to gain insight into:

a) The extent to which students find the facilities, services and information sources of the different libraries

difficult or easy to use;

b) Which facilities, services, or information sources students find more difficult to use than others;

c) The correlation between ease of use and library instruction received. 
The reasons for undertaking this research were, in the first instance, to use the results as a tool to measure or benchmark the ease of use of the Library Services, and secondly, to use the results as input for planning ways to make the library's services and facilities easier to use, where necessary.

\section{Research methods}

Although the research described in this article was performed simultaneously at all the libraries of Technikon Pretoria, the remainder of this article will, for the sake of conciseness, report only on an investigation done at one of the Technikon's libraries in the Mpumalanga province. The library was selected for reporting purposes because it renders a large variety of services and the students using the library are a fair representation of the broader student population of Technikon Pretoria.

A questionnaire (see Appendix I) was designed to gather the information needed. During the last week of August 200I, five hundred questionnaires were made available at the entrance of the library. During that time all the questionnaires were taken by students and $30 \mathrm{I}$ questionnaires were returned before the end of the survey period. The response rate was $29.51 \%$ of the total student population of that particular campus.

Because a non-probability sampling technique was used, the results were likely not as representative as would have been the case if a probability sampling technique were used. However, if taken into account that the population response was relatively high, it can be assumed that the results are reliable and significant enough to make valid conclusions. Furthermore, because the results showed that the majority of respondents are very active library users (almost $93 \%$ of the respondents use the library at least once week), it is fair to assume that the survey managed to get information from those students who were able to give a meaningful input.

The results of the survey were entered into Excel, a spreadsheet program, and converted to SAS (Statistical Analyses Software Package, Version 8. I). Frequency tables for all variables, and cross-tabulation tables for selected variables were generated.

\section{Findings and analysis}

\section{Academic year enrolled}

The majority of respondents $(53.1 \%)$ were enrolled in their first academic year; $26.4 \%$ were in their $2^{\text {nd }}$ year, $15.7 \%$ in their $3 \mathrm{rd}$ year and only $4.8 \%$ of the respondents were in their 4 th year of enrolment. The value of these figures are that they give library staff an indication of who their primary users are, so that they may plan library instruction programs and activities accordingly, to make the library more user friendly.

\section{Frequency of library use}

The results showed that the respondents at this particular campus are very active library users; $71.3 \%$ of the respondents use the library almost every day, and a further $21.2 \%$ of the respondents use the library about once or twice a week. The remaining respondents were divided evenly between those who use the library about once a month and those who use it seldom.

The fact that $92.5 \%$ (cumulative percentage) of respondents use the library at least once a week is an indication to library staff that initiatives to enhance the ease of use of the library should be a continuous and important part of the library's agenda.

\section{Ease of use}

The results relating to ease of use are summarised in Table I. These are presented in a descending order ranging from activties that most students find easy to use, to activities that the least number of students find easy to use. It is clear from Table I that the majority of respondents find the following activities either very easy or easy to use:

- Using the photocopiers (88.6\% combined frequency);

- Borrowing books (78.6\% combined frequency);

- Getting assistance from the library staff (70.3\% combined frequency);

- Finding their way in the library (67.9\% combined frequency);

- Obtaining information from the library staff (67.0\% combined frequency).

The results mentioned above were to a large extent predictable because the activities concerned are fairly straightforward, and would under normal circumstances not involve much difficulty to understand or to perform. 
Table I The ease of use of library services, facilities and information sources

\begin{tabular}{|c|c|c|c|c|c|c|c|c|c|c|}
\hline \multirow[t]{2}{*}{ How easy is it to ... } & \multicolumn{2}{|c|}{ Very easy } & \multicolumn{2}{|c|}{ Easy } & \multicolumn{2}{|c|}{$\begin{array}{c}\text { Somewhat } \\
\text { difficult }\end{array}$} & \multicolumn{2}{|c|}{$\begin{array}{c}\text { Very } \\
\text { difficult }\end{array}$} & \multicolumn{2}{|c|}{$\begin{array}{c}\text { ** Not } \\
\text { applicable }\end{array}$} \\
\hline & $\mathbf{n}$ & $\%$ & $\mathbf{n}$ & $\%$ & $\mathbf{n}$ & $\%$ & n & $\%$ & $\mathbf{n}$ & $\%$ \\
\hline use the photocopiers? & 193 & 64.6 & 66 & 22.0 & 26 & 8.7 & 11 & 3.7 & 3 & 1.0 \\
\hline borrow books? & 137 & 46.0 & 97 & 32.6 & 22 & 7.4 & 17 & 5.7 & 25 & 8.4 \\
\hline find your way in the library? & 118 & 39.5 & 85 & 28.4 & 65 & 21.7 & 30 & 10.0 & 1 & 0.3 \\
\hline $\begin{array}{l}\text { get assistance from the } \\
\text { library staff? }\end{array}$ & 100 & 33.3 & 111 & 37.0 & 44 & 14.7 & 32 & 10.7 & 13 & 4.3 \\
\hline $\begin{array}{l}\text { obtain information from } \\
\text { the library staff? }\end{array}$ & 72 & 24.0 & 129 & 43.0 & 60 & 20.0 & 28 & 9.3 & 11 & 3.7 \\
\hline find items on the shelves? & 37 & 12.3 & 129 & 43.0 & 81 & 27.0 & 47 & 15.7 & 6 & 2.0 \\
\hline $\begin{array}{l}\text { find items that have been } \\
\text { reserved for assignments? }\end{array}$ & 53 & 17.9 & 102 & 34.3 & 87 & 29.3 & 41 & 13.8 & 14 & 4.7 \\
\hline $\begin{array}{l}\text { know where the different } \\
\text { collections (i.e. books, } \\
\text { reference works, journals, } \\
\text { etc.) are? }\end{array}$ & 52 & 17.6 & 121 & 40.8 & 79 & 26.7 & 28 & 9.7 & 16 & 5.4 \\
\hline $\begin{array}{l}\text { find information on a } \\
\text { specific topic or subject? }\end{array}$ & 40 & 13.7 & 112 & 38.4 & 82 & 28.1 & 38 & 13.0 & 20 & 6.9 \\
\hline borrow periodicals? & 40 & 13.7 & 83 & 28.4 & 49 & 16.8 & 25 & 8.6 & 95 & 32.5 \\
\hline use multimedia? & 18 & 6.2 & 69 & 23.7 & 65 & 22.3 & 36 & 12.4 & 103 & 35.4 \\
\hline $\begin{array}{l}\text { use the online computer } \\
\text { catalogue (Opac/Webpac)? }\end{array}$ & 9 & 3.1 & 33 & 11.4 & 46 & 15.9 & 51 & 17.6 & $|5|$ & 52.0 \\
\hline
\end{tabular}

As shown in Table I, a noticeably smaller percentage of respondents indicated that the following activities are either very easy or easy to perform:

- Knowing where the different collections (e.g. books, reference works, journals, etc.) are. (58.4\% combined frequency);

- Finding items on the shelves (55.3\% combined frequency);

- Finding items that have been reserved for assignments ( $52.3 \%$ combined frequency);

- Finding information on a specific topic or subject ( $52.1 \%$ combined frequency).

It is also noticeable that the four activities mentioned above are all related to locating information resources or information in the library. Those activities also require, to some extent, knowledge or skills that students usually gain from library orientation given to them by library staff at the beginning of the academic year.

The following group of activities were regarded either very easy or easy to perform by the smallest percentage of respondents:

- Borrowing periodicals ( $42.1 \%$ combined frequency);

- Using multimedia (29.9\% combined frequency);

- Using the online computer catalogue (14.5\% combined frequency).

Apart from the relatively small percentage of respondents who found the last three activities either very easy or easy to perform, it is also noticeable from Table I that a relatively high percentage of students responded "not applicable" to the three activities in question. As explained in Table I, the "not applicable" option could be used by respondents if they were either unaware of the existence of the service or facility in question, or have not used the service or facility. The reason why such a large number of respondents marked the questions as "not applicable" is unknown, but one of the possible explanations could be that they perceived the activity in question too difficult to use.

What comes as a surprise to the researcher is that it was much more difficult for students to borrow periodicals than to borrow books. Compared to $78.6 \%$ of the respondents that said it was either easy or very easy to borrow books, the corresponding percentage for borrowing periodicals is $42.1 \%$. It is also noticeable that $32.5 \%$ of the respondents indicated that they have not yet borrowed periodicals or were unaware of the existence of the service. A similar pattern is found in the results regarding the use of multimedia. A possible explanation could be that users of the particular library were not very familiar with periodicals and multimedia as sources of information, or how to search and retrieve such sources. 
Another noticeable finding is that the use of the library's online computers was regarded by the lowest percentage of students to be either very easy or easy to use. Only $3.1 \%$ of the respondents regarded it as very easy to use and only $11.4 \%$ regarded it easy to use. It is also noticeable that more than half $(52.1 \%)$ of the respondents indicated that they haven't yet used the online computer catalogue. A possible explanation for this situation could be that using the online computer catalogue demands far more knowledge and skill than any of the other activities listed in the questionnaire.

\section{The relationship between library instruction received to the ease of use of library services, facilities and information sources}

A large number $(77.1 \%)$ of the respondents indicated that they have received library instruction.

With the aid of cross-tabulation tables produced by a statistical analysis software program, the results for students who received library instruction and those who did not receive instruction, were related to the results regarding the ease of use of particular library services, facilities and information sources. The variables selected for comparison purposes were all included in the library's user instruction lectures at the beginning of the academic year.

The data produced by the cross-tabulation tables is summarised in Table 2.

Table 2 Relation between library instruction received and ease of use of library services, facilities and information sources

\begin{tabular}{|c|c|c|c|c|c|c|c|c|c|c|}
\hline \multirow[t]{2}{*}{ How easy is it to... } & \multicolumn{2}{|c|}{ Very easy } & \multicolumn{2}{|c|}{ Easy } & \multicolumn{2}{|c|}{$\begin{array}{c}\text { Somewhat } \\
\text { difficult }\end{array}$} & \multicolumn{2}{|c|}{$\begin{array}{c}\text { Very } \\
\text { difficult }\end{array}$} & \multicolumn{2}{|c|}{$\begin{array}{c}* * \text { Not } \\
\text { applicable }\end{array}$} \\
\hline & 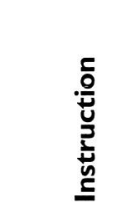 & 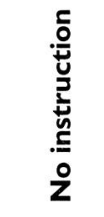 & 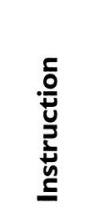 & 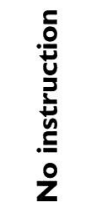 & 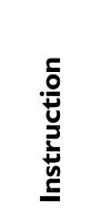 & 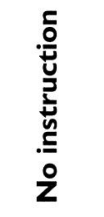 & .̊. & 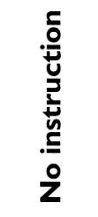 & & 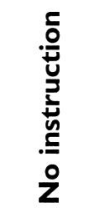 \\
\hline $\begin{array}{l}\text { find information on a } \\
\text { specific topic or subject? }\end{array}$ & $86.8 \%$ & $13.2 \%$ & $80.7 \%$ & $19.3 \%$ & $77.5 \%$ & $22.5 \%$ & $62.2 \%$ & $37.8 \%$ & $55.0 \%$ & $45.0 \%$ \\
\hline borrow books? & $83.7 \%$ & $16.3 \%$ & $77.7 \%$ & $22.3 \%$ & $76.2 \%$ & $23.8 \%$ & $64.7 \%$ & $35.3 \%$ & $50.0 \%$ & $50.0 \%$ \\
\hline borrow periodicals? & $83.8 \%$ & $16.2 \%$ & $85.4 \%$ & $14.6 \%$ & $68.1 \%$ & $31.9 \%$ & $56.0 \%$ & $44.0 \%$ & $77.7 \%$ & $22.3 \%$ \\
\hline use multimedia? & $70.6 \%$ & $29.4 \%$ & $86.6 \%$ & $13.4 \%$ & $82.5 \%$ & $17.5 \%$ & $63.9 \%$ & $36.1 \%$ & $71.0 \%$ & $29.0 \%$ \\
\hline $\begin{array}{l}\text { use the online computer } \\
\text { catalogue (Opac/Webpac)? }\end{array}$ & $75.0 \%$ & $25.0 \%$ & $87.9 \%$ & $12.1 \%$ & $87.0 \%$ & $13.0 \%$ & $75.5 \%$ & $24.5 \%$ & $71.2 \%$ & $28.8 \%$ \\
\hline $\begin{array}{l}\text { know where the different } \\
\text { collections (i.e. books, } \\
\text { reference works, journals, } \\
\text { etc.) are? }\end{array}$ & $82.0 \%$ & $18.0 \%$ & $79.5 \%$ & $20.5 \%$ & $77.9 \%$ & $22.1 \%$ & $71.4 \%$ & $28.6 \%$ & $43.7 \%$ & $56.3 \%$ \\
\hline Weighted average & $83.0 \%$ & $17.0 \%$ & $82.0 \%$ & $18.0 \%$ & $78.8 \%$ & $21.2 \%$ & $67.3 \%$ & $32.7 \%$ & $70.6 \%$ & $29.4 \%$ \\
\hline
\end{tabular}

** The column "Not applicable" indicated that respondents are either unaware of the existence of the service or facility in question, or have not used the service or facility.

Of those respondents who indicated that it was either very easy or easy to perform a particular library activity, the majority (weighted averages $83.0 \%$ and $82.0 \%$ respectively) had received library instruction. It therefore seems that students in this particular library who regarded certain library activities to be easy or very easy, might have benefited by receiving library instruction.

Surprisingly, of those respondents who found the six library activities either somewhat difficult or very difficult to perform, the majority (weighted averages $78.8 \%$ and $67.3 \%$ respectively) also received library instruction. Here it seems that students who experienced certain library activities difficult to perform have not benefited by receiving library instruction, as would have been expected or hoped. A possible explanation is that lecturing as a mode of library instruction does not equip students sufficiently to perform activities expected from them. Another reason might be that factors not relating to library instruction, (i.e. insufficient sources and equipment) influenced students of this library to regard certain library activities difficult to perform. 


\section{Users' comments}

In response to an open-ended question 69 (23\%) respondents used the opportunity to elaborate on their answers and to give additional comments. Because several respondents commented on more than one issue, the number of comments does not correspond with the number of respondents.

Thirty-seven of the replies were either statements or complaints regarding the high level of noise in the library. Thirty-six respondents stated or complained that the library was too small. It was interesting to note that in many cases the respondents who complained about the lack of space were the same who complained about the noise. Other comments dealt with gratitude to library staff (9), a need for more computers (5), a need for more information sources (5), staff attitudes (2), and a complaint that the library is too cold.

Although the respondents did not link their comments to a specific question or answer in the questionnaire, their comments are nevertheless informative and valuable because they highlight problems and issues not covered by the structured questions. In addition, the users' comments suggest that some of the reasons why students find the library difficult to use could be directly or indirectly related to a lack of library space and too much noise in the library.

\section{Conclusion}

The findings of a survey presented in this article shed some light on the type of library services, facilities and information sources that undergraduate students at a satellite campus find either easy or difficult to use. These will enable the managers of the library to focus on specific problem areas and do follow-up research to identify the reasons why students find it difficult to use specific services and facilities, and how to eliminate or reduce those reasons. The findings also indicate that further research is still needed to reach more definite conclusions about the influence of library instruction, lack of space, and high levels of noise on the ease of use of library services, facilities and information sources.

Peer libraries, public libraries and even school libraries can use these findings to gain more insight into the library use of young adults, or to compare the findings to their own situations.

Apart from the research topics already suggested, researchers can take this work forward by broadening the scope to include other user groups and other library types into the investigation.

\section{References}

Allan, M. et al. 2002. Personalized library services; innovative Web-based reference services: a selected list. American Library

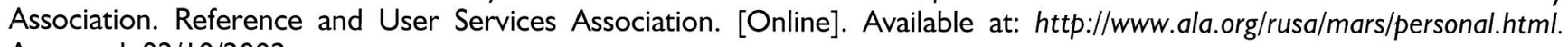
Accessed: 02/10/2002

Arbor, A. 1996. Interactive reference assistance saves students trips to the library. The University of Michigan News and

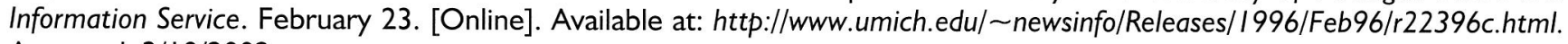
Accessed: 2/10/2002

Bosman, E. 1997. Creating a user friendly library with signage: The Indiana

University Northwest experience. [Online]. Available at: $h t t p: / / w w w . i u n . e d u / \sim$ libemb/signage/ Accessed: 02/10/2002.

Metcalf, K.G. 1985. Planning academic and research library buildings. New York: McGraw-Hill.

\section{Appendix I. Questionnaire}

Technikon Pretoria Library Services

\section{Library User Survey}

The Library Services of Technikon Pretoria is conducting this survey to gather input from you and other students of Technikon Pretoria to help us make its libraries as pleasant and easy to use as possible.

Your inputs will also be used to compile a second questionnaire that will focus on issues that need improvement. Please take a few minutes to respond to the following questions. We welcome your feedback!

If you already completed this questionnaire in another library, it is important that you fill it out again. This time you are representing this library.

\section{Section A. General information}

Please mark the appropriate boxes.

\section{Al. Academic year enrolled.}

\begin{tabular}{|l|l|l|l|}
\hline Ist year & 2nd year & 3rd year & 4th year \\
\hline
\end{tabular}


A2. At what campus do you attend most of your classes?

\begin{tabular}{|l|l|l|l|l|l|l|}
\hline Technikonrand & Arts & Arcadia & KwaMhlanga & Nelspruit & Pietersburg & Witbank \\
\hline
\end{tabular}

A3. How often do you use a library at Technikon Pretoria?

\begin{tabular}{|l|l|l|l|l|}
\hline Almost every day & About once or twice a week & About once or twice a month & Seldom & Never \\
\hline
\end{tabular}

\section{A.4 Have you received any library instruction?}

\begin{tabular}{|l|l|}
\hline Yes & No \\
\hline
\end{tabular}

\section{Please turn over}

\section{Page 2}

\section{Section B. How easy is it to use the library?}

Please mark the appropriate box next to each question. If you haven't used a specific service or facility yet, please mark the "Not applicable" box.

How easy is it to find your way in the library?
B2 How easy is it to find items on the shelves?
B3 How easy is it to find items that have been reserved for
B4 How easy is it to find information on a specific topic or subject?
B5 How easy is it to borrow books?
B6 How easy is it to borrow periodicals?
B7 How easy is it to use multimedia?
B11 How easy is it to obtain information from the library staff?
B12 How easy is it to get assistance from the library staff?
B10 How easy is it to use the photocopiers?




\section{Section C. General comments}

Please use this space if you want to elaborate on your answers.

We sincerely appreciate the time and care you took to complete this survey.

After completing the questionnaire, please post it in the box marked "Library User Survey" at the library exit. 